Tr ansf or mat i ons of Mercury, I ron, and Sul fur during the Reductive Di ssol uti on of I ron- oxyhydroxi de by Sulfide

\begin{tabular}{|c|c|}
\hline 著者 & Aar on J. Sl oewy, Gor don E. Br own Jr. \\
\hline $\begin{array}{l}\mathrm{j} \text { our nal or } \\
\text { publ i cat } \mathrm{i} \text { on } \mathrm{ti} \mathrm{tl} \mathrm{e}\end{array}$ & $\begin{array}{l}\text { Pr ontt i on Envi r nment al Resear ch i n Pan- Japan } \\
\text { Sea Ar ea - Young Resear cher s' Net wor k- : } \\
\text { Abot r act }\end{array}$ \\
\hline page $r$ ange & $93-94$ \\
\hline year & $2006-0308$ \\
\hline URL & ht t p: //hdl . handl e. net /2297/6544 \\
\hline
\end{tabular}




\title{
Transformations of Mercury, Iron, and Sulfur During the Reductive Dissolution of Iron-oxyhydroxide by Sulfide
}

\author{
Aaron J. Slowey ${ }^{(a)}$ and Gordon E. Brown, Jr. ${ }^{(a, b)}$

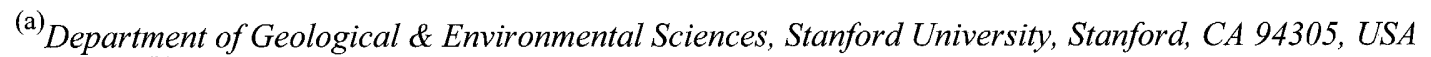 \\ ${ }^{(b)}$ Stanford Synchrotron Radiation Laboratory, SLAC, Menlo Park, CA, 94025, USA
}

Methylmercury can accumulate in fish to concentrations unhealthy for humans and piscivorous birds. Most sources of mercury $(\mathrm{Hg})$ emit inorganic species to the environment. Therefore, ecological harm occurs when inorganic Hg is converted to methylmercury. Sulfate- and iron-reducing bacteria methylate $\mathrm{Hg}$. Processes promoting the potential bioavailability of inorganic $\mathrm{Hg}$ under conditions in which these bacteria live are poorly understood. Here we show that sulfide initially decreases the concentration of dissolved and adsorbed $\mathrm{Hg}$ in the presence of iron-oxyhydroxide (Figure 1), forming $\mathrm{HgS}$ (Figure 2). However, sulfide-promoted dissolution of iron-oxyhydroxide eventually dissolves $\mathrm{HgS}$ via formation of ferrous iron-bearing species [ $\mathrm{Fe}(\mathrm{II})]$ (Figure 1). Our results demonstrate that $\mathrm{HgS}$ is much less recalcitrant in the presence of $\mathrm{Fe}(\mathrm{II})$ compared to sulfide. The formation of $\mathrm{HgS}$ in $\mathrm{Hg}$-contaminated wetland or marine sediments may not effectively limit bioavailability under conditions that promote the activity of iron-reducing bacteria. Our results emphasize the importance of considering iron in addition to sulfur speciation to effectively predict whether processes promoting $\mathrm{Hg}$ bioavailability are likely to dominate. Sulfur and iron speciation are useful geochemical indicators of ecological risk posed by $\mathrm{Hg}$.

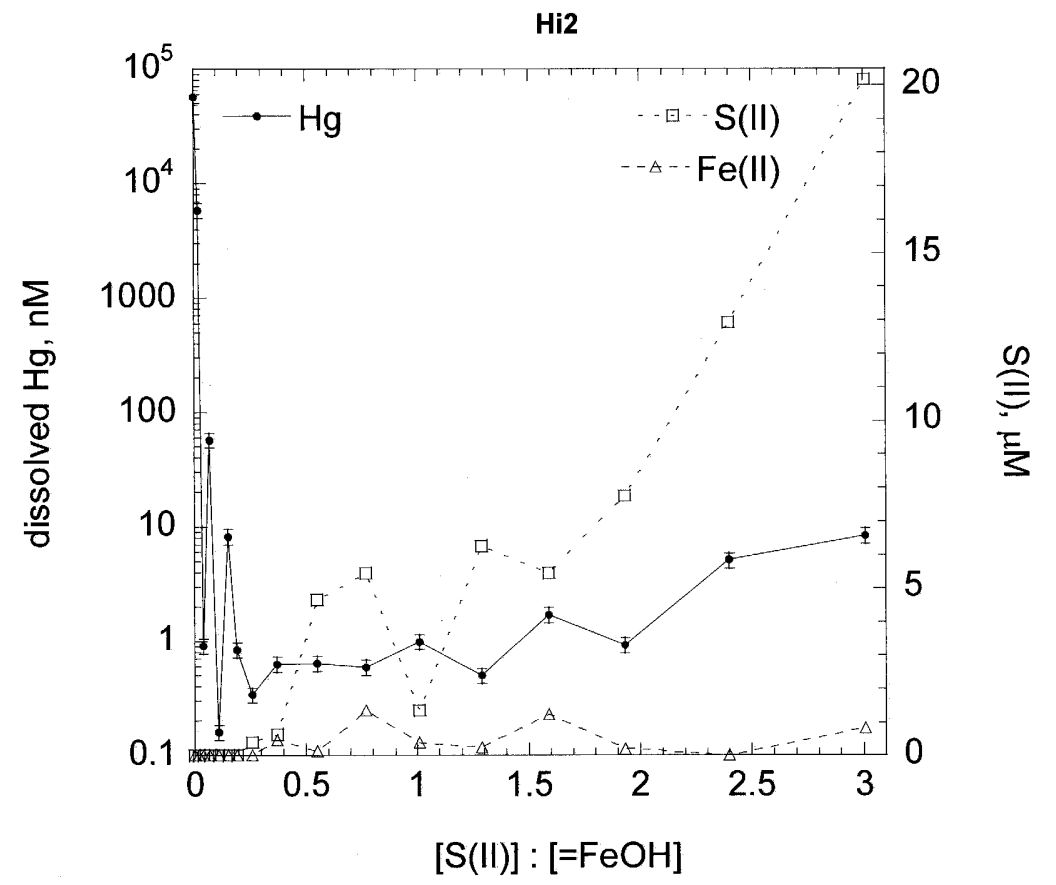

Figure 1 Concentrations of dissolved $\mathrm{Hg}$ (left axis), $\mathrm{Fe}(\mathrm{II})$, and $\mathrm{S}$ (II) (right axis) during sulfide addition at a normalized rate of $2.8 \mu \mathrm{M}$-sulfide $\mathrm{m}^{-2}$-goethite surface area $\mathrm{h}^{-1}$. The unit of the $\mathrm{x}$-axis is an estimated mole-ratio of sulfide to goethite surface sites, assuming a constant goethite surface area of $90 \mathrm{~m}^{2} \mathrm{~g}^{-1}$ and a site density of 6 sites $\mathrm{nm}^{-2}$.

(a) electronic address: aslowey@pangea.stanford.edu, URL: http://pangea.stanford.edu/research/saag/aaron.htm
(b) electronic address: gordon@pangea.stanford.edu 


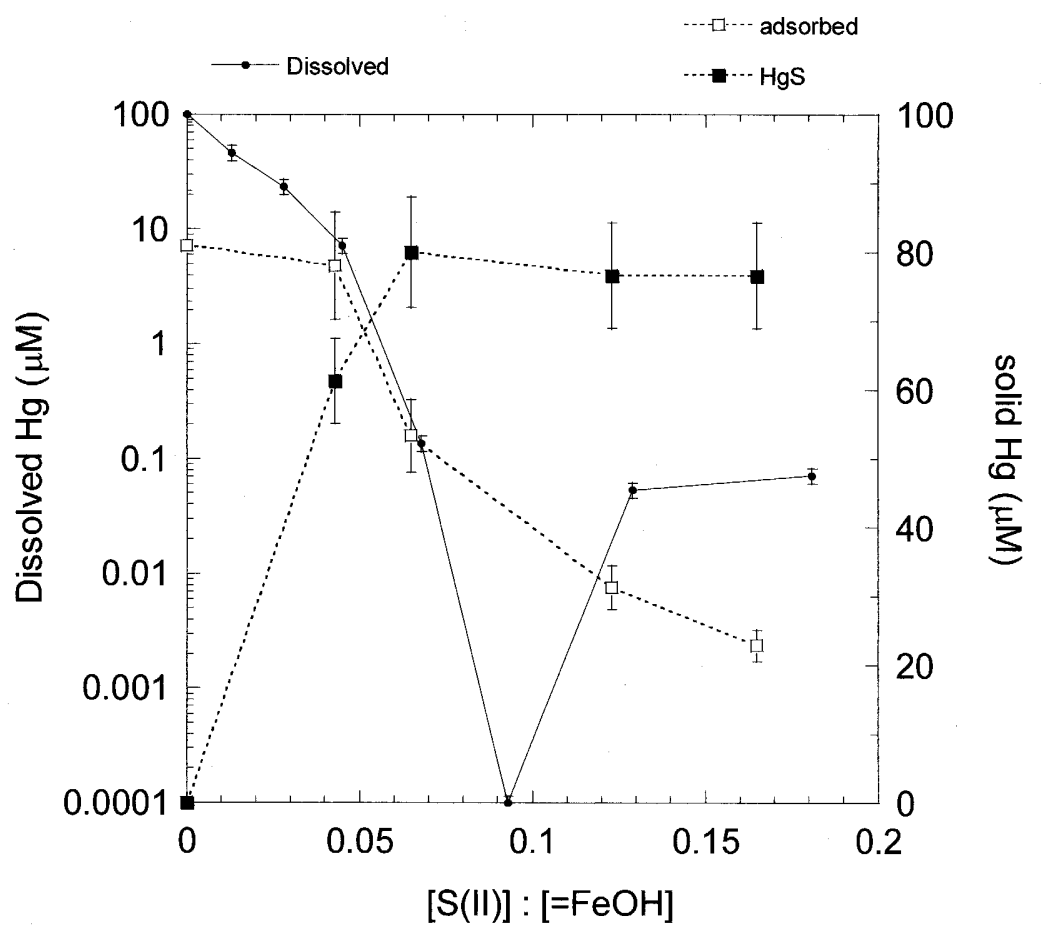

Figure 2 Phase-distribution and solid-phase molecular speciation (right axis) of mercury during sulfide addition at a normalized rate of $0.6 \mu \mathrm{M}$ sulfide $\mathrm{m}^{-2}$-goethite surface $\mathrm{h}^{-1}$. See the caption of Figure 1 for an explanation of the $\mathrm{x}$-axis unit.

\section{Methods}

A stirred flow reactor was utilized to apply sulfide concentration gradients $\left(0.6\right.$ and $\left.2.8 \mu \mathrm{M} \mathrm{m}^{-2} \mathrm{~h}^{-1}\right)$ to $5 \mathrm{~g} \mathrm{~L}^{-1}$ goethite suspsensions onto which $0.2 \mu \mathrm{mol}-\mathrm{Hg} \mathrm{m}^{-2}$ was adsorbed at $\mathrm{pH} 7.4 \pm 0.1$. The reactor was purged with nitrogen and samples were taken into a glass syringe, closed, and processed in a $2 \%$ hydrogen $+98 \%$ nitrogen-filled glove bag. Dissolved constituents were defined as those capable of passing $0.2 \mu \mathrm{m}$ filters. Dissolved $\mathrm{Hg}$ was measured using cold vapor atomic fluorescence spectroscopy (USEPA Method 1631). Dissolved ferrous iron [Fe(II)] was analyzed using the ferrozine assay. Dissolved sulfide was measured using the methylene blue colorimetric assay. The speciation of $\mathrm{Hg}$ in the solid phase was investigated using extended X-ray absorption fine structure (EXAFS) spectroscopy at the $\mathrm{Hg} \mathrm{L}_{\mathrm{III}}$ edge at the Advanced Photon Source, Argonne, Illinois, USA. Particles for EXAFS analysis were mounted on polyethersulfone membranes, dried under $2 \%$ hydrogen $+98 \%$ nitrogen, and sealed in Kapton film. 